Research Article

Marion Khan

\title{
Ethical dilemmas in sharing transformative experiences with patients in a clinical setting: A Reflective Account
}

https://doi.org/10.2478/ijtr-2021-0001

received 30 September, 2021; accepted 2 November, 2021

\begin{abstract}
I write this article as a postgraduate researcher undertaking a doctorate in Education, with an interest in research as a transformative process, and fascinated by the debate as to whether reality is objective or subjective. In reflecting on this, I recalled a significant incident that occurred when I was Professional Education Lead in an NHS hospital. I had been asked to work with a nurse, who had been disciplined as a consequence of talking about her Christian faith with a patient. The nurse was assuming that, in sharing experiences that were transformative for her, she might also transform the patient's perception of her own illness and its meaning. As a Christian myself, I was caught in a situation where I could understand the conflicting perspectives of all key players, including the patient, her family, the nurse, and the NHS managers. I explore how I mediated my way through this situation, aiming to do justice to all perspectives, and the ethical dilemmas I faced when having to choose between personal and professional values. As a consequence of this incident, I have learned that, not only is transformation a deeply personal experience, but because it is either influenced by, or leads to, a specific world view, it supports the idea of reality being subjective rather than objective.
\end{abstract}

Keywords: nursing; prayer; transformative; ethical, dilemma

\section{Professional Context}

As a qualified nurse I recently held the post of Professional Education Lead for a large NHS Foundation Trust, support-

*Corresponding author: Marion Khan, School of Education, York St John University, Lord Mayor's Walk, York Y031 7EX, E-mail: marion. khan@yorksj.ac.uk ing the education and training of clinical staff. In addition, I am a Christian. My role brought me into contact with Staff Nurse Anne (anonymised) who had been referred to me by her Ward Sister because of an incident that had occurred when she was caring for a patient on Elderly Care. While talking to an elderly, and very poorly, female patient (Mrs M), Anne shared her strong Christian beliefs and indicated that such a faith brings comfort and reassurance at a time of illness. Anne asked if she could say a short prayer at the bedside for Mrs $M$, to which the patient agreed. The patient listened to the prayer, and thanked Anne when she left. Subsequently however the family of the patient made a formal complaint about the inappropriateness of such an action between a nurse and a patient, that their relative was elderly and unwell, and Anne's actions were "taking advantage of a vulnerable patient to further her own beliefs". As a result of the complaint Anne was disciplined, received a Written Warning, and was referred to me by my manager for professional education support.

This significant incident took place sometime ago but on thinking about it recently I recall the personal and professional issues and challenges that arose. At the heart of the incident are the stories of individuals who are drawn together because of a transformative experience. Everyone looked at the reality of this incident from their own distinct, but interconnecting, perspective and an ethical dilemma had developed as these individual perspectives unfolded. In this article I will discuss the stories involved in this ethical dilemma, my own included, and my role in mediating a personal pathway through it that aimed to do justice to all.

\section{Anne's Story}

Following Anne's disciplinary outcome, I had received a request from my manager to work with Anne to identify the issues she needed to consider regarding professionalism, appropriate nursing care and patient interactions, 
and to support her through the development of strategies and approaches to prevent such a situation arising again. This incident was significant in both Anne's life and professional practice, with potentially serious consequences for her nursing career if she continued to actively present her Christian beliefs to patients.

My meetings with Anne disclosed her story. Anne was fully aware that directives within her professional code of practice and terms of employment stated she could not 'preach' in patient settings as this would be viewed as proselytizing. Anne had maintained her adherence to these directives, not acting on her desire to share her faith, until the incident occurred with Mrs M. A conflict had then arisen for Anne when areas within her personal and professional spheres collided. Faith beliefs held in one domain, and regulatory/professional guidelines in the other, had come face to face.

Anne's Christian belief and faith arose from a sense of conviction that was "totally life-changing", and which had occurred after attending a local church service the previous year. She recounted that she had received a deeply "internalized" transformative experience with God that was almost physical in its intensity, and which gave her a clear mission to share the joy and peace of her faith with those she met. We discussed her role as a nurse with these faith convictions, and she believed that not only had her personal awareness of compassion as a core nursing value been deeply enriched by her transformative Christian experience, but she was also enabled to demonstrate an enhanced level of caring professionalism within her practice.

Anne established that her relationship with Mrs M was no different from other patients, but on entering the room that morning she saw Mrs M was extremely upset. Anne said a sense of overwhelming compassion overtook her, and placing her hand over those of Mrs M, she asked what the matter was. It appeared Mrs M was feeling low about her ongoing illness and was concerned she would never improve and be able to return to her home. At this point Anne said she received an overwhelming awareness of great spiritual distress in Mrs M. This awareness compelled her to ask if she could say a prayer for Mrs M to receive comfort from distress, and courage to face each day of her illness. Anne told me that this was the first time she had ever faced such feelings of engulfing compassion, and truly believed it had arisen from the transformative nature of her earlier faith experience. Mrs M agreed to the request, and Anne said a short prayer while still holding Mrs M's hands. Afterwards Mrs M thanked her, and Anne left. The following morning Anne was informed a formal complaint had been made by Mrs M's family about the prayer, and it was only at this point that Anne was aware the ethics of her action had been called into question.

Linking care, compassion, and professionalism in nursing with a Christian ethos is certainly reflected in the literature (Wright, 2009, Ellis \& Narayanasamy, 2009), and Straughair (2012, p. 163) states that

"The notion of compassion in nursing can be attributed to the Christian ideals translated by Florence Nightingale into the characterization of the professional nurse"

But as noted by Paley (2009) and Begley (2009), linking nursing attributes such as compassion and professionalism with a faith belief may be fraught with ethical controversy. The Nursing and Midwifery professional code (NMC, 2015, Sec 20.7, p. 15) stated that nurses must "make sure you do not express your personal beliefs (including political, religious or moral beliefs) to people in an inappropriate way”. Further, the Spiritual Care Guidelines of the NHS Trust where I worked clearly stated that only the professional Chaplaincy or Spiritual Care Team can deliver a spiritual care service to patients. The Guidelines go on to advise that healthcare staff do have a responsibility to show awareness of the spiritual care dimension but should make patient referrals to Chaplaincy if required. The disciplinary process thus found Anne in breach of both the professional conduct expected of a Registered Nurse, and as an employee of the Trust.

Anne's interpretation of this guidance, which she expressed at her disciplinary hearing, was that she was responding to the spiritual, not religious, needs of her patient. She was not proselytizing, preaching, or trying to convert the patient but supporting her at a time of personal crisis in the way Anne believed would be most helpful. Further, the NMC Code (NMC, 2015, Sec 2.3, p. 5) itself did not state anywhere that a nurse cannot offer to pray for a patient, rather nurses are required to "encourage and empower people to share decisions about their treatment and care"- the position Anne considered she was taking. Additional uncertainties arose from the NMC nursing standards (NMC, 2018, Platform 3, p. 13) which identified the practice and decision making competencies nurses must demonstrate, and which Anne quoted at her disciplinary meeting, requiring nurses to "prioritise the needs of people when assessing and reviewing their mental, physical, cognitive, behavioural, social and spiritual needs....to identify the priorities and requirements for person-centred and evidenced-based nursing interventions and support”. Again, Anne believed this was the course of action she was taking. Anne acknowledged that a complaint had come forward following her 
prayer with Mrs M, but challenged that this created an ethical dilemma - rather, she felt she was doing the best for her patient through the giving of person-centred care at the point of need. As a nursing professional Anne did accept the outcome of the Panel however and confirmed that she would not offer prayer or other faith interventions to patients in the future.

\section{Mrs M's Story}

Mrs M was an elderly, and very poorly, female patient that had been on the Elderly Care Ward for six weeks. She was suffering with several areas of ill health, made worse by a persistent chest infection that was exhausting for her. Mrs $M$ had been widowed for several years, and while living an independent life at home, relied heavily on the input of her son and his family to maintain that independence. Her prolonged stay in hospital, and the continual feeling of ill health, was becoming very distressing for Mrs M who feared she may no longer be able to return to her home and live independently. As a result, she had become quite disheartened, and was distressed at the prospect of perhaps being transferred to a residential home on discharge. It was against this backdrop that Anne, on seeing Mrs M very anxious and upset that morning, felt compelled to share her strong Christian beliefs and indicated that such a faith brings comfort and reassurance at a time of illness and anxiety. Anne was at her bedside, took her hand, and then offered to say a short prayer. Mrs M agreed for Anne to do this and listened while Anne closed her eyes and freely spoke a short prayer asking for Mrs M's anxiety to be replaced by peace and calm, and for her speedy recovery. When Anne opened her eyes Mrs M thanked her for her prayer, not expressing any feelings of unease about what had just happened, and Anne then left the room. When later asked about the incident by the Ward Sister, Mrs M said she did not feel under any pressure from Anne to agree to her request to pray or felt she was trying to convert her to a Christian faith. While Mrs M did confirm that she would not have asked for prayer herself as she felt this was too personal and private, nonetheless she felt the experience with Anne was "nice".

Until the offer of prayer was given to and accepted by Mrs M, Anne's actions may perhaps be construed as the 'engaged spirituality' championed by Wright and Neuberger (2012, p. 20) where nurses "just need to source their own deeply felt humanity from which compassionate action flows with ease and grace". The question remains however - was it ethical for Anne to step over the line of appropriate nursing behaviour by initiating an offer of prayer to Mrs M? From personal experience at the bedside, I am aware that a listening ear and a caring approach can often give a high level of comfort and reassurance to patients who are distressed. Further, Anne was aware that she could have offered to refer Mrs M to the Chaplaincy or Spiritual Care teams whose specific roles are to offer counselling, support and, if required, religious intercession, but she did not.

The care Mrs M was receiving may presuppose that her perspective was one of trust in her nurse to do the best for her. Smeyers (1999, p. 242) asserts that the action of trusting "restricts the interpretations we will consider as possibly applying to the words and actions of another" whereby we make assumptions that the person to be trusted has integrity, is reliable, and fosters a true concern and respect for the person who trusts. We do not know what level of trust Mrs M had in Anne, but in describing her feelings of distress, she had perhaps demonstrated her level of trust but also made herself vulnerable through the projection of confidence in her nurse. And being trusted, which can be understood as a personal tribute, may have encouraged the sense of overwhelming compassion and care Anne believes came from her transformative Christian experience, resulting in the offer of prayer. As a result of the disciplinary procedures Anne was no longer able to care for Mrs M, either during or after the process. Mrs M was aware of her family's complaint, but it may be that she was not aware of the disciplinary consequences for Anne. During my discussions with Anne, she mentioned that Mrs M had asked her colleagues where she was on a couple of occasions. Mrs M had been correctly told that Anne, because of the family concerns, was now working on another part of the ward. I have no way of knowing whether this knowledge was upsetting or not for Mrs M, but she had clearly developed a relationship with Anne, and this relationship had now come to an end.

\section{The Family's Story}

While it transpired Mrs M did not appear to personally have issue with the prayer at the time, her family expressed the view that Anne's action in requesting to pray had applied pressure to their elderly relative, who had then been put into an uncomfortable position and unable to refuse. The NMC Code requires nurses to "work in partnership with people to make sure you deliver care effectively" (NMC, 2015, Sec 2.1, p. 4) and goes on to define the "fundamentals of care" (ibid, p. 4) as the practical 
elements of nutrition, hydration, physical handling etc. These fundamentals are certainly the visible expectations of good nursing care, where their enactment is achieved through the behaviours of a 'giver' of care (nurse) and a 'receiver' of care (patient) (Noddings, 2013). The family stated that Mrs M had been given, and received, excellent nursing care while on the ward, and that they all felt very much in a 'partnership' with the ward staff. And it was in the spirit of this partnership that they felt compelled to bring forward the complaint. They said that Mrs M herself was not complaining about Anne's offer to pray, but their interpretation of Anne's action was that it amounted to a form of abuse - abuse of their frail relative, and abuse of the power that Anne held as Mrs M's nurse. As a result, the partnership had now become skewed. An ethical dilemma had developed. The motivation for Anne's offer of prayer - her transformative Christian experience - was not considered as relevant by the family in their complaint, it was the offer itself to Mrs M that was their concern. The disciplinary process was therefore triggered because Anne initiated the offer of a prayer even though she had subsequently obtained consent before verbally commencing to pray. The issue at the centre of the complaint for the family was that Mrs M had not requested prayer, and as they did not believe this is something Mrs M would have naturally done, they believed Anne had thus acted outside of her professional role and responsibility as the nurse caring for their relative. The family felt very strongly that Mrs M had been coerced into agreeing to participate in a prayer action, and as a result the partnership relationship with Anne had been broken for both themselves and Mrs M. At the core of this partnership relationship had been 'trust' - trust in the nurse, other ward staff, and the organization. The family did not label the issues they raised as an ethical dilemma, rather that Anne's action had abused the sense of trust that they, and Mrs M, had placed in her. The perspective which gave rise to the family's complaint was not based on a sense of moral principles, rather on the standard of behaviour they had come to expect from a nurse and caring organisation. They felt there had been a failure in this standard, and the trust of the partnership relationship had been broken at every level.

\section{My Manager's Story}

The disciplinary process had found Anne in breach of her professional conduct as a nurse by initiating an approach to pray with the patient. As a result, my manager was required to ensure Anne received professional education support and would not offer prayer or any religious intercession to patients in the future. My manager told Anne she had respect for the strong, transformative Christian beliefs she held, and could appreciate that in caring for Mrs M that morning Anne felt "compelled" to offer prayer. The overriding perspective of the Disciplinary Panel, and of my manager, was that the professionalism of both the Trust and Anne had been damaged because of the ethical dilemma her actions had brought about - whatever the source or motivation for those actions might be. As a result, my manager wanted to ensure this ethical dilemma was both acknowledged and accepted by Anne and would not be repeated.

From a professional perspective my manager had concerns about the level of empowerment Mrs M may, or may not, have felt during this encounter, and the knowledge/ power position Anne inhabited. Anne, after all, was the health care professional who held the 'knowledge' and understood the bewildering environment, procedures and activities surrounding Mrs M, a frail and very poorly elderly lady (Christensen \& Hewitt-Taylor, 2006). The traditional paternalistic approach in healthcare has shifted however, balances of power are relocating from the clinical experts to the patients themselves, and healthcare professionals must be "critically aware of the attitudes, beliefs and values they hold in relation to patient empowerment" (Christensen \& Hewitt-Taylor, 2006, p. 695). The benefits of patient empowerment where the culture is of shared power, respect and encouraging patients to self-manage, has thus reversed to some extent the historical paternalistic approach to healthcare (Christensen \& Hewitt-Taylor, 2006). Nonetheless, as highlighted by Foucault (1995), action is the exercise of power. By asking Mrs $M$ if she could say a prayer for her (albeit driven by the best of intentions sourced from her transformative Christian experience), my manager felt Anne's action could be said to have enacted power over her patient. My manager agreed it was not that Anne did not care enough or was not guided by a caring ethic, but rather that her knowledge status gave her greater power than Mrs M, and she had offered to pray from this power position. From my manager's perspective, the ethical dilemma arose from conflict between the profession and organisation (regulatory and policy guidance), Anne's position (transformative belief experience and knowledge status), and the position of Mrs M and her family (empowerment, respect, and encouragement). Ultimately my manager wanted to ensure that professional and organisational guidance was maintained in the Trust to give a clear direction to staff, and reassurance to patients and their relatives. The transformative Christian experience which Anne believed com- 
pelled her to initiate the prayer offer was thus regarded by my manager as in conflict with the professional role of a nurse, and created the ethical dilemma. My manager therefore wanted Anne to gain insight into this perspective of the dilemma, and that whatever Anne's personal beliefs and faith standpoints, they were to always remain just that - entirely personal.

\section{My Story}

Following the disciplinary outcome for Anne, my manager requested that I work with her to unpick the events of the incident and place those events, and her role as a nurse, in a professional context. Our meetings took place over several weeks, my position sometimes that of coach and sometimes that of mentor, but overall, I believe that of a professional and supportive colleague. Through these meetings and the information, I received from the Disciplinary Panel, I became aware of the differing perspectives and personal stories that arose from this ethical dilemma.

As a qualified nurse and the Professional Education Lead for the Trust, my role was to design, deliver, and support the education and training of clinical staff across the organisation. In addition to this I am also a committed Christian. And I was aware of the challenge of this situation - Anne and I were both nurses, both Christians, both working in very busy healthcare environments, and both trying to juggle faith perspectives in a setting which does not endorse or encourage open discussions of faith beliefs with patients. Of course, I was able to empathise with her situation and although I cannot say I felt the compulsion of a recent transformative faith experience, I was able to reflect on my own position as a nurse and a Christian in such a setting. I believe it was this reflection that enabled me to see more clearly the perspective that Anne held, but I would argue that my sense of a professional self also enabled me to appreciate the perspectives of the patient, the family, my manager, and the organization which resulted in an ethical dilemma.

I was required to deliver professional education support to Anne, but I did not interpret this as a requirement for me to make Anne 'see the error of her ways'. Seen through my own personal and professional lenses, I felt she was trying to deliver ethical caring to Mrs M and truly believed she was engaging in the human effective response as described by Noddings (2013). She saw that Mrs M was very distressed and took this as an objective need in her patient, to which she reacted. Through my professional lens I can see that Anne was focusing on her patient as the cared-for, in her nursing role as the one-caring, through the relationship of interaction. A point Noddings (2013, p. 19) makes in her work is that "the one caring, in caring, is present in her acts of caring" and because of this can identify where everything wished for cannot be achieved or undertaken. And perhaps this is what overcame Anne at the time of the incident - she was able to identify that Mrs $M$ was very upset, and why, but felt unable to practically do anything to relieve the distress other than pray. But in reality, of course this was not the case as Anne was aware - she could have asked if Mrs M would like to speak to someone from Chaplaincy, she could have asked if Mrs M would like to contact a member of her family or a friend, or whether she would just like to talk with Anne about her concerns. From speaking with Anne about her transformative experience I can appreciate the Christian prayer response she felt at a personal level. From a professional level, I query whether this was the right action to take because it was initiated by Anne in the moment. Noddings (2013) stipulates the importance of the reciprocal, two-way, flow of communication where the ethical ideal in the caring relationship is manifested through dialogue and acceptance of the best of intentions. Certainly, Anne had the best of intentions, but the reciprocity of the situation I believe appears somewhat strained - Mrs M did not ask for prayer, but the dialogue was already established by Anne's offer, and therefore the resulting communication and acceptance by Mrs M was perhaps not, as her family maintained, a reciprocal encounter. The dilemma had formed.

There is ethical ambiguity in including prayer in nursing care (Winslow \& Winslow, 2003, Ledger, 2005) as, over time, the secularization of medicine has increased and a more scientific view come forward (Narayanasamy, 1999). And while studies have indicated a connection between prayer, religious beliefs, and good physi$\mathrm{cal} /$ mental health where patients receiving intercessory prayer experience significantly improved health outcomes compared to participants in the control group (Koch, 2008, Narayanasamy \& Narayanasamy, 2008, Cha, Wirth \& Lobo, 2001), other studies have suggested that prayer has no healing influence at all (Krukoff, Crater \& Gallup, D. 2005, Benson, Dusek, \& Sherwood, 2006). My belief in the comfort, even effectiveness, of prayer and the act of praying exists, in alignment with Anne's perspective. As stated earlier, to bring the Christian faith into nursing can be an undertaking "fraught with landmines of political correctness and sensibilities" (Fawcett \& Noble, 2004, p. 138) because of regulatory and organisational guidelines, and the professional direction that "you must not use your professional status to promote causes that are not related 
to health" (NMC, 2015, Section 21.5). When I consider the caring ethic that underpins the nursing profession and, I suspect, the still existing power position of the nurse in caring for her patient, I do believe that Anne did not act appropriately in offering to pray for Mrs M. As the holder of knowledge Anne did not fully consider the situation of Mrs M but may have unconsciously used her more powerful position to assume that her offer of prayer was acceptable.

I reflect on the considerations of Anne's belief in her transformative experience, the response of Mrs M and the complaint by the family, the decision of the Disciplinary Panel, the directive from my manager, and the regulatory body and organisational guidelines. Stephen Wright (2009, p. 27) in the Nursing Standard considers that "we have junked the Christian values inherited from Florence Nightingale, but what has replaced them to inform our ethical decisions? Secular values will produce different results in policy making”. My role in this incident was to work with the policy values that underpinned the disciplinary outcome, whatever my personal beliefs may be. While I was able to empathise with Anne during our meetings, my professional focus was to fully discuss the ethical dilemma that had developed when bringing a transformative faith experience into a clinical environment. The conversations with Anne were challenging because I was aware my own faith position was on a direct collision course with Anne's when balanced against professional perspectives. I do not believe Anne ever truly accepted that the position of the Disciplinary Panel was valid, but she was a professional, and assured me that she would not be drawn to pray for patients in the future and would refer them on appropriately.

My discussions with Anne did give rise to distracting thoughts of my own however, and to which I can only perhaps look to the future - if we believe that nursing now exists in a secular realm, only able to refer patient anxieties crying out for prayer interventions to a Chaplaincy or Spiritual Care Team, does this process not deny nurses of Christian, and other faiths, the opportunity to practice their beliefs in their work environment? In desiring to support the policy and guideline structures of today where nurses are not permitted to approach their patients with the offer of prayer, are we not in fact denying the human rights or causing offence to nurses of faith who consider their beliefs require them to intercede on behalf of their patients? I believe this is a challenge for nursing today. And while, in this incident, I believe that Anne was incorrect in offering to pray for Mrs M despite her transformative Christian experience, the ethical dilemma itself has raised a wider challenge. It would take a bold move to embed into nursing practice, healthcare organisations, and the NMC, the opportunity for nurses of any faith to be supported in offering to share prayer with their patients but I believe it is worth exploring the challenge. Nurses work very closely with their patients, getting to know them, their families, and friends, sometimes over a considerable period. A bold move indeed would be to work towards an agreed, organizational, and regulatory body accord, whereby nurses of faith could offer prayer to patients rather than the sole option of making referrals. Naturally some patients may prefer this, but for others who have been cared for and have developed a close professional relationship with their named nurse, there may be a preference for a praying relationship to also develop.

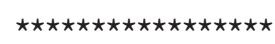

Now, several years later and as an EdD postgraduate researcher, I have revisited the central role of Anne and the ethical incident. Looking back, I can acknowledge that mediating the situation between the faith of my own Christian beliefs and the ethics of my professional role was extremely difficult. And yet the situation was no different for Anne - she too was caught in the mesh of two juxtaposing positions, that of faith and that of profession. Considering the ethical dilemma now however, against the backdrop of those juxtaposing positions, I can see that there is also the debate about whether reality is subjective or objective.

Anne's connection with her transformative faith experience was, as she described, so overpowering that it shifted her established thinking in a significant and deep way and subsequently changed the way she viewed the world. Her subjective reality from where she perceived, evaluated, or felt what is believed to be real was, I believe, totally reshaped. Her human response to the faith experience she had encountered created a transformation and a central shift in perspective, resulting in lasting changes to her sense of self, perception of relationship to the world around her, and her way of being (Schlitz, 2010). For Anne, her objective reality was the transformative experience she had encountered in church the previous year. She saw the situation as concrete, there was no room for interpretation, rather her experience 'is'. But her perception of that experience is subjective, it is what she perceived, and a conscious reaction to her objective reality. I would submit further that in the domain of subjective reality, real can be anything that has a valid effect on the person who perceives it. For Anne, her sense of self moved to an intense internalised knowing that the power of God can help those in distress, and this subjective reality was 
so strong that it comprised a total, and valid, truth for her. Anne's perception of the world, and her Christian role within it, became her way of being - this was a totally personal involvement, this was her reality, sourced from an objective church experience that was transformative and formed the construct of her subjective view.

On the day of the incident, I believe Anne's knowing went beyond a wish to share this truth with Mrs M. Rather, Anne assumed that in sharing what she perceived as the authentic effect of the subjective reality that had come out of her transformative experience, she might also transform Mrs M's perception and meaning of her illness. Anne's transformative experience which formed her subjective reality, and reshaped worldview, could not have the same effect on the worldview and perceptions of Mrs M, her family, or indeed any other key player involved in the ethical dilemma, myself included. It is from this vantage point that I believe the dilemma arose.

\section{Conclusion}

In looking back at the factors that merged to form this ethical dilemma, I must admit to a feeling of unease. It is true that, as obliged by the incident, Anne's actions were subject to review by the Disciplinary Panel, the concerns of the family addressed, and managerial/intervention steps taken to clarify issues and support Anne for the future. The transformative Christian encounter that Anne experienced was, from my perspective as I now look back, like a stone thrown into a pond. The ripples spread outwards, changing the landscape, and only returning to a calm pond surface once all the ripples had run their course. Anne felt compelled to offer prayer, this was agreed to by Mrs M, as a result her family forwarded a complaint, in consequence Anne appeared before the Disciplinary Panel, the Panel report was sent to my manager, I was asked to support Anne with professional and organizational education, and she agreed not to offer faith interventions to patients in future. The pond surface became calm again. Or did it? I am aware of the many unanswered questions that arose in the immediate aftermath - what did Anne really think about her belief perspectives and the result of the dilemma, how did Mrs M really feel when she learnt Anne could no longer care for her, were the family really content with the outcome and consequences of their complaint, was this really the only course open to satisfy professional and organizational policies, and have I really reconciled my dual perspectives of a professional nurse and Christian believer in this ethical dilemma, and could there really be an opportunity in the future for nurses to offer prayer to their patients? But I am also now aware of a further ripple in the pond, that not only is transformation a deeply personal experience, but because it is either influenced by, or leads to, a specific world view, it supports the idea of reality being subjective rather than objective. Anne's subjective reality belonged to Anne, no-one can see or feel what she felt, share her experiences, recall her memories, or stand in her shoes. Our perceptions are what we rely upon to orientate ourselves and form our world view, but I believe we must also develop insight on the impact that world view may indirectly and subconsciously have on others.

The impact of Anne's transformative experience and the dilemma that arose will forever remain with these, and many other, similar questions. The incident has been dealt with, but questions surrounding the outcome of the ethical dilemma will, I suspect, linger in my memory.

\section{References}

[1] Begley, A. (2009) Secular is good. Nursing Standard, 24 (13), 26-27.

[2] Benson, H., Dusek, J. \& Sherwood, J. (2006) Study of the therapeutic effects of intercessory prayer in cardiac bypass patients. A multicenter randomised trial of uncertainty and certainty of receiving intercessory prayer. American Heart Journal, 151 (4), 934-942.

[3] Cha, K., Wirth, D. \& Lobo, R. (2001) Does prayer influence the success of in vitro fertilisation-embryo transfer? Journal of Reproductive Medicine, 46 (9), 781-787.

[4] Christensen, M. \& Hewitt-Taylor, J. (2006) Modern nursing. Empowerment in nursing: Paternalism or maternalism? British Journal of Nursing, 15 (13), 695-699.

[5] Dunbar, K., Fugelsang, J. \& Stein, C. (2007). Do naïve theories ever go away? Using brain and behavior to understand changes in concepts. In M. Lovett \& P. Shah (Eds). (2007). Thinking with Data (pp. 193-205). Mahwah, NJ: Lawrence Erlbaum Associates.

[6] Dunbar, K.N. (2008). What scientific thinking reveals about the nature of cognition. In K. Crowley, C.D. Schunn \& T. Okada (Eds). (2008). Designing for Science: Implications from Every Day, Classroom, and Professional Settings (pp. 103-126). Mahwah, NJ: Lawrence Erlbaum Associates.

[7] Ellis, H.K. \& Narayanasamy, A. (2009) An investigation into the role of spirituality in nursing. British Journal of Nursing, 18 (14), 886-890.

[8] Fawcett, T.N. \& Noble, A. (2004) The challenge of spiritual care in a multi-faith society experienced as a Christian nurse. Journal of Clinical Nursing, (2), 136.

[9] Foucault, M. (1995). Discipline and punish: The birth of the prison. New York, USA: Vintage Books.

[10] Koch, J. (2008) Is religion a health resource for the poor? The Social Science Journal, 45, 497-503. 
[11] Krukoff, M., Crater, S. \& Gallup, D. (2005) Music, imagery, touch, and prayer as adjuncts to interventional cardiac care: The monitoring and actualisation of noetic trainings (MANTRA) II randomised study. The Lancet, 366 (9481), 211-217.

[12] Ledger, S. (2005) The duty of nurses to meet patients' spiritual and/or religious needs. British Journal of Nursing, 14 (4), 220-225.

[13] Narayanasamy, A. (1999) Learning spiritual dimensions of care from a historical perspective. Nurse Education Today, 19 (5), 386-395.

[14] Narayanasamy, A. \& Narayanasamy, M. (2008) The healing power of prayer and its implications for nursing. British Journal of Nursing, 17 (6), 394-398.

[15] Noddings, N. (2013). Caring: A relational approach to ethics \& moral education. 2nd ed. Berkeley, California: University of California Press.

[16] Nursing \& Midwifery Council [NMC] (2015) The code. London, UK: Nursing \& Midwifery Council.
[17] Nursing \& Midwifery Council [NMC] (2018) Future nurse: Standards of proficiency for registered nurses. London, UK: Nursing \& Midwifery Council.

[18] Paley, J. (2009) Keep the NHS secular. Nursing Standard, 23 (43), 26-27.

[19] Schlitz, M. (2010) Worldview Transformation and the Development of Social Consciousness. Journal of Consciousness Studies, 17 (7-8), 18-36.

[20] Smeyers, P. (1999) 'Care' and wider ethical issues. Journal of Philosophy of Education, 33 (2), 233.

[21] Straughair, C. (2012) Exploring compassion: Implications for contemporary nursing. Part 1. British Journal of Nursing, 21 (3), 160-164.

[22] Winslow, G. \& Winslow, W.B. (2003) Examining the ethics of praying with patients. Holistic Nurse Practitioner, 17 (4), 170-177.

[23] Wright, S. \& Neuberger, J. (2012) Why spirituality is essential for nurses. Nursing Standard, 26 (40), 19-21.

[24] Wright, S. (2009) The ethics of care. Nursing Standard, 24 (8), 26-27. 